\title{
Shallow-Water Benthic Communities on California's Outer Continental Shelf
}

\author{
G. S. Lewbel ${ }^{1}$, A. Wolfson ${ }^{2}$, T. Gerrodette ${ }^{3}$, W. H. Lippincott ${ }^{4}$, J. L. Wilson ${ }^{5}$ \\ and M. M. Littler ${ }^{6}$ \\ 1 LGL Ecological Research Associates, 1410 Cavitt Street, Bryan, Texas 77801, USA \\ 2 International Biological Consultants, 819 DeWitt Avenue, Encinitas, California 92024, USA \\ 3 Box 76, Rural Route Number One, Del Mar, California 92014, USA \\ 413549 Calais Drive, Del Mar, California 92014, USA \\ $s$ Science Applications, Inc., 464 Prospect Street, La Jolla, California 92037, USA \\ 6 Department of Ecology and Evolutionary Biology, University of California, Irvine, California 92717, USA
}

\begin{abstract}
Benthic macroinvertebrates and macrophytes were studied at depths from about 20 to $30 \mathrm{~m}$ on Cortes and Tanner Banks, $180 \mathrm{~km}$ offshore from San Diego, California, USA. The structure of these communities is described in terms of percentage cover, biomass, species diversity, and species evenness. Two distinctly different communities were present. The shallow-water community was best developed above $25 \mathrm{~m}$ depth, and dominated by the southern sea palm Eisenia arborea which formed dense stands on ridges and pinnacles. The community below $30 \mathrm{~m}$ was characterized by the encrusting red coralline alga Lithophyllum proboscideum. Remote from shore and weather-beaten, Cortes and Tanner Banks harbor subtidal communities whose relative species abundances differ from those of comparable depths near the southern California mainland and Channel Islands.
\end{abstract}

\section{INTRODUCTION}

Cortes and Tanner Banks are the tops of undersea mountains that rise abruptly from ocean basin depths approximately $180 \mathrm{~km}$ west of San Diego, California, USA (Fig. 1). Projecting into the mainstream of the California Current, Cortes and Tanner Banks have a combined area of approximately 33,900 ha (99 nautical miles $^{2}$ ) of high-relief rocky shoals less than $100 \mathrm{~m}$ deep, lying within $5 \mathrm{~km}$ of the $750-\mathrm{m}$ isobath. The habitat available for shallow-water marine life on these banks is $37 \%$ greater in area than the subtidal flanks (to $100 \mathrm{~m}$ depth) of San Clemente Island, the nearest California Channel Island. Far from shore and exposed to the full force of open ocean storms, the Banks are characterized by clear water (visibility usually greater than $20 \mathrm{~m}$ ), strong currents (typically 0.2 to $0.7 \mathrm{~m} \mathrm{~s}^{-1}$ ), and rough weather (waves up to $11 \mathrm{~m} \mathrm{high}$ ) (Ecomar, 1978). They are the first shallow submarine features on the continental shelf to interrupt the passage of deep ocean swells. Cortes and Tanner Banks lie close enough to the California coast to be colonized by propagules of nearshore marine fauna and flora. However, environmental conditions which shape development of shallow marine communities on the banks are oceanic rather than neritic in character.

During 1976 and 1977, the Pacific Outer Continental Shelf Office of the US Bureau of Land Management (BLM) sponsored the first comprehensive study of the subtidal ecology of these remote areas. This report summarizes the results of shallow-water descriptive community studies conducted jointly for the BLM by Science Applications, Inc. and by the University of California.

\section{MATERIALS AND METHODS}

Four study sites, two on Cortes Bank and two on Tanner Bank, were selected after a preliminary bathymetric and visual inspection. The sites were chosen to be representative of major habitat types, level enough for photographic transect methods, located near bathymetrically distinct bottom features to aid relocation, shallow enough to permit SCUBA diving without decompression, and adequately deep to permit divers to work in comparatively calm conditions on the bottom despite rough surface weather. Each site was 
marked with surface and subsurface buoys and with acoustic pinger systems on the sea floor. Sites were visited in September, October, and December 1976 , and April and May 1977

Three surveying methods were employed: photography, in situ observation, and harvest sampling, all done by SCUBA divers. A photographic technique, the point intercept method (Littler, 1971), provided quantitative information on standing crops of subtidal organisms. Two $20 \times 1-m$ transects and about a dozen permanently marked quadrats were established at each site. Field notes furnished additional information on species not seen in photographs, and included observations of organisms (e.g., fish) not sampled by other methods. Some organisms were collected as voucher specimens to confirm visual and photographic identifications, and to generate as complete a species list as possible. Twelve $1-\mathrm{m}^{2}$ quadrats were harvested at each site to provide data on biomass and to identify small or cryptic species. After larger organisms in the harvest quadrats had been collected by hand, an underwater airlift captured material loosened by scraping tools. This technique worked well for all organisms except encrusting coralline algae, which could not be easily detached from the substrate.

Quadrats and transects were placed haphazardly within study sites. Due to uneven bottom topography, it was not possible to locate transects and quadrats in a statistically random fashion. As a consequence, the hydrocoral Allopora californica may have been underrepresented, since it tended to occur on pinnacles and cliff edges unsuitable for our sampling methods. Photographs and preserved organisms were identified taxonomically and used for biomass determinations. Percentage cover in transects and gross wet weight in harvested quadrats were selected as indices of species abundance patterns, with community summaries provided by the Shannon-Weaver diversity index $\left(\mathrm{H}^{\prime}\right)$ and the Pielou evenness index $\left(J^{\prime}\right)$ (Pielou, 1966a,b).

This program emphasized visually dominant invertebrates and plants that could be readily seen and identified in the field and in photographs. Not all organisms could be identified to the species level. We believe that such taxonomic omissions had little effect upon benthic community summary statistics, since all calculations were based upon percentage cover, and most forms large enough to be seen in a photograph could be easily identified. The species list is least complete for invertebrates and plants smaller than $0.5 \mathrm{~mm}$ in size.

Although not censused, demersal fish associated with the rocky substrate were abundant, especially the rockfishes Sebastes mystinus and $S$. serranoides, the sheepshead Pimelometopon pulchrum, the señorita Oxyjulis californica, the rock wrasse Halichoeres semi- cinctus, the blackeye goby Coryphopterus nicholsii, the ocean whitefish Caulolatilus princeps, and many others. A number of open-ocean pelagic fish were seen, including the yellowtail Seriola dorsalis, the California flyingfish Cypselurus californicus, the blue shark Prionace glauca, another unidentified large carcharinid or lamnid shark, and others. Many sea lions (Zalophus californicus) were observed feeding on the fish and leaping out of the water.

\section{RESULTS}

The results of this study will be described site-bysite. As neither strong nor consistent temporal changes were present for most species, the data from each site will be presented as single values averaged over all sampling visits. An overview of visually dominant species at each site is illustrated in Figure 2.

\section{North Cortes}

The North Cortes study site was situated on the top of one of the many extended ridges that divided the sea bottom into valleys (depth about $30 \mathrm{~m}$ ) and parallel crests (depth about $20 \mathrm{~m}$ ). These ridges were covered with dense stands of the southern sea palm Eisenia arborea, whose density decreased with depth on the sides of the ridges. Strong currents and surge kept the ridges relatively free of unconsolidated sediment.

Beneath the meter-high canopy of Eisenia arborea at the study site was an understory of smaller brown and red algae, including Dictyota flabellata, Pachydictyon coriaceum, and Rhodymenia spp. Prominent invertebrates were the jewel anemone Corynactis californica,

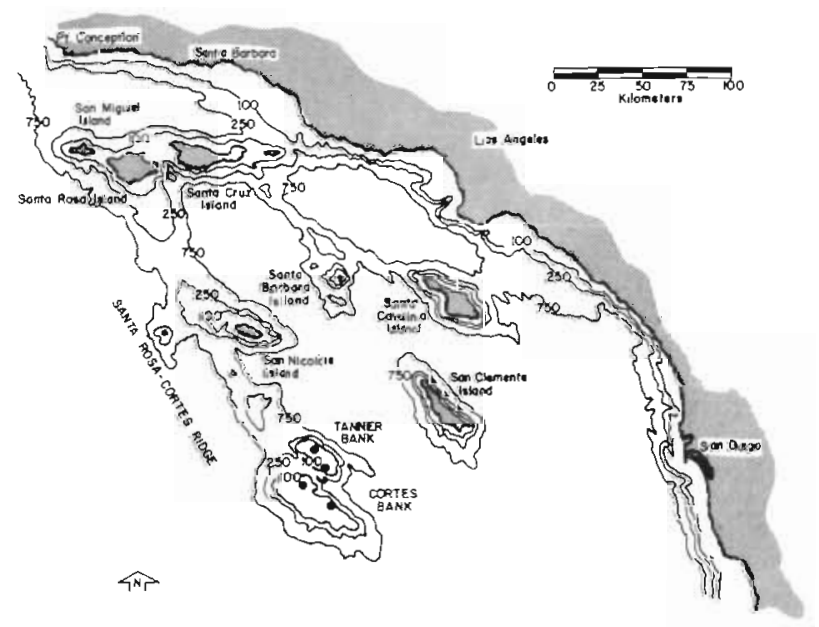

Fig. 1. Locations of study sites (dots) on Cortes and Tanner Banks with respect to other southern California continental shelf features. Contours are in meters 

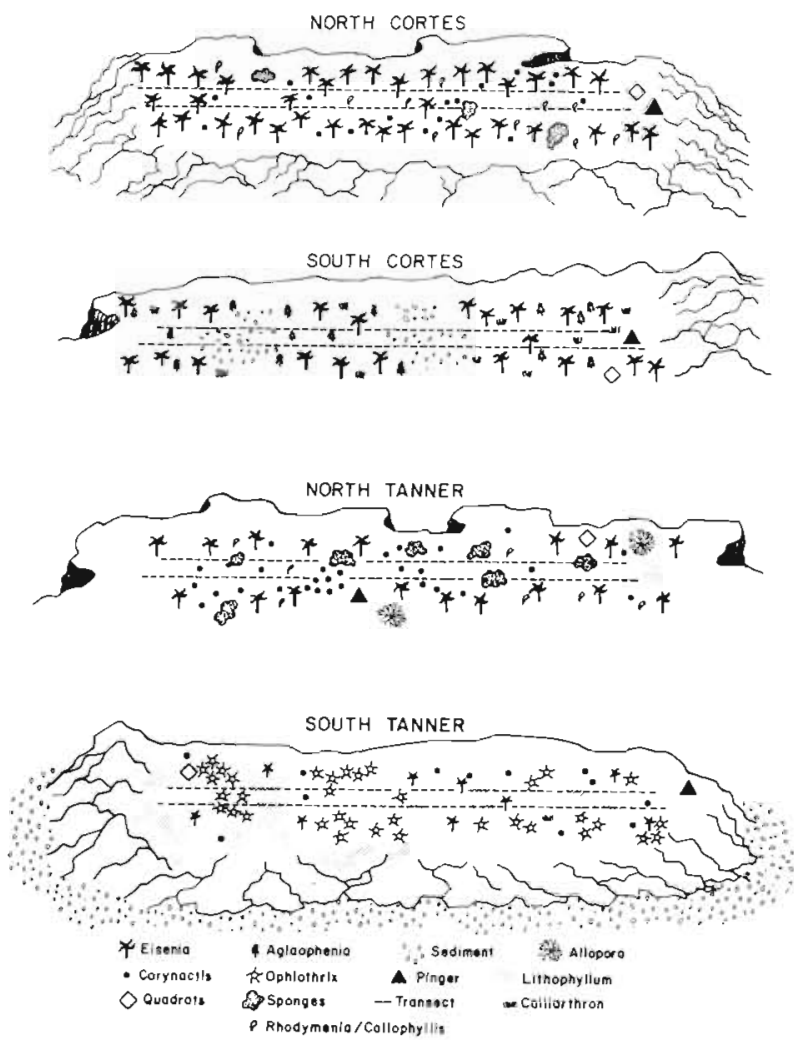

Fig. 2. Schematic illustration of study sites, showing topography and visually dominant organisms symbolically represented

the hydroids Aglaophenia spp. and Abietinaria spp., the barnacle Balanus tintinnabulum californicus, the pelecypods Modiolus spp., Hiatella artica, and Chlamys hastata, and the sponge Tethya aurantia. Cracks and crevices on the sides of the ridge sheltered the spiny lobster Panulirus interruptus, the crab Cancer jordani, and the sea urchin Strongylocentrotus franciscanus.

The two transect lines paralleled the axis of the ridge, covering a visually rather homogeneous area. In all, 94 macrophyte taxa and 46 macroinvertebrate taxa were recognized (Fig. 3A, Table 1). Phyla with the most taxa among the macrophytes and macroinvertebrates were Rhodophyta and Mollusca, respectively (Fig. 4). Eisenia arborea was the dominant alga in terms of percentage cover $(48 \%)$, while Corynactis californica $(13 \%)$ and various sponges ( $7 \%$ ) were the most abundant macroinvertebrates (Fig. 5). Total macrophyte cover was $109 \%$ (overstory plus understory), compared to total macroinvertebrate cover of $31 \%$. Diversity $\left(\mathrm{H}^{\prime}\right)$ averaged $0.61,1.31$, and 1.65 for macroinvertebrates, macrophytes, and the two combined, respectively (Fig. $3 \mathrm{~B})$. Corresponding values for evenness $\left(\mathrm{J}^{\prime}\right)$ were 0.23 , 0.44 , and 0.46 (Fig. 3C).

The total wet weight averaged $5855 \mathrm{~g} \mathrm{~m}^{-2}$ (Fig. 3D), of which $5156 \mathrm{~g}(88 \%)$ was due to Eisenia arborea (Fig. 6). As with percentage cover in the transects, Corynactis californica had the highest wet weight (94 $\mathrm{g} \mathrm{m}^{-2}$ ) among the macroinvertebrates harvested. Strongylocentrotus franciscanus, by contrast, had the second highest macroinvertebrate wet weight $(85 \mathrm{~g}$ $\left.\mathrm{m}^{-2}\right)$ although its average percentage cover was very low $(<0.1 \%)$. S. franciscanus was relatively uncom-
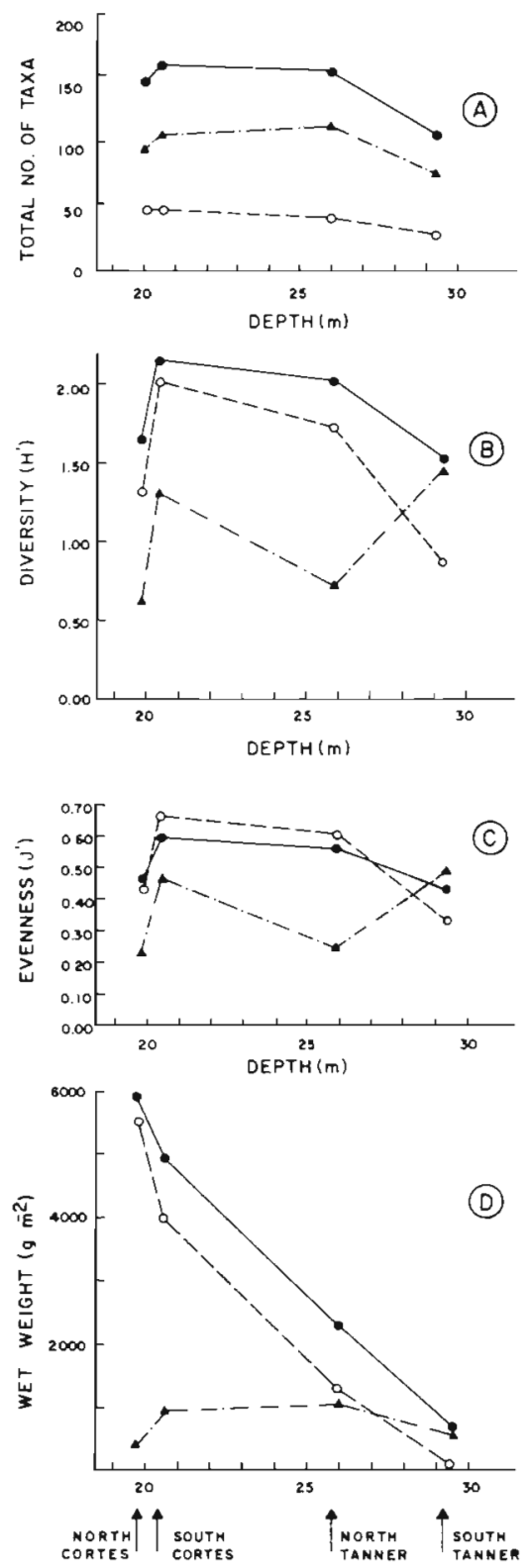

Fig. 3. Distribution of (A) total taxa, (B) species diversity, (C) species evenness, and (D) wet weight, as a function of depth at each study site 

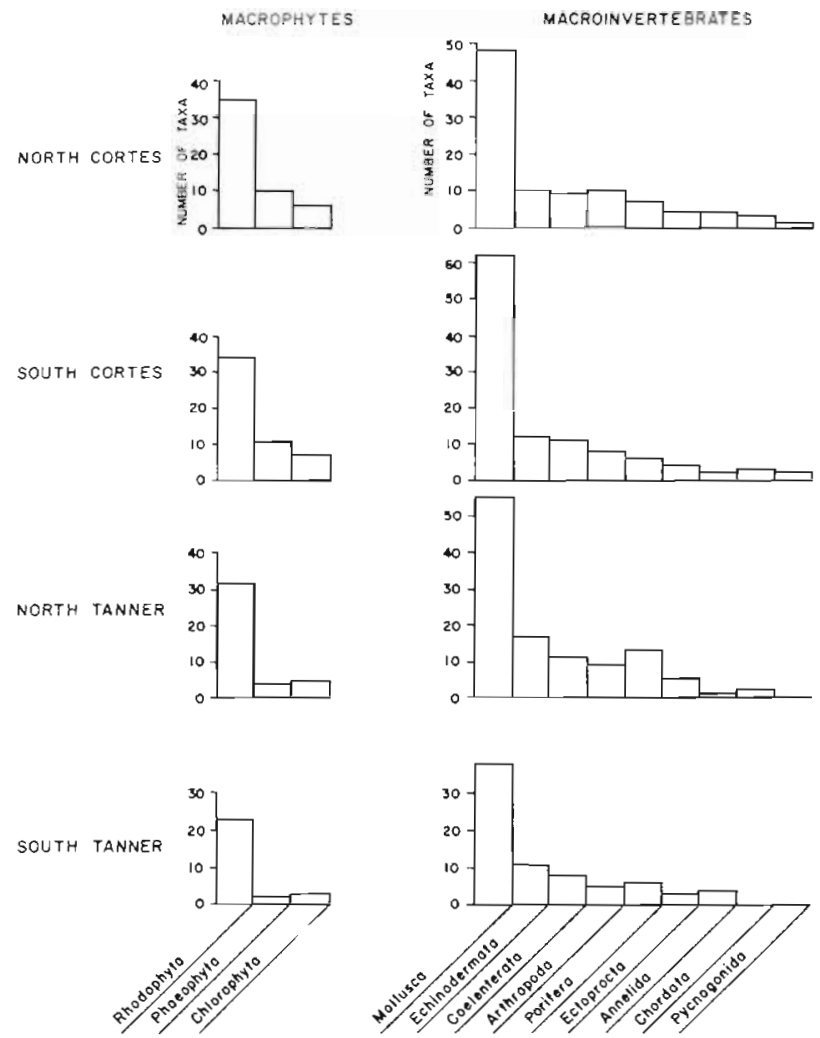

Fig. 4. Distribution of biota by number of taxa identified in major macrophyte and macroinvertebrate groups

mon, but a few of these large urchins happened to occur within the harvested quadrats, accounting for their high recorded biomass figure at the North Cortes site.

\section{South Cortes}

The South Cortes study site was located within view of the US Coast Guard buoy on Bishop Rock. Just slightly deeper than the North Cortes site, South Cortes (between 20 and $21 \mathrm{~m}$ ) was surrounded by ridges covered with Eisenia arborea, but included many rock outcrops which projected between depressions filled with shifting, coarse unconsolidated sediment. The two transects and the quadrats were located in the somewhat protected area below the crests of nearby ridges. The flora and fauna of South Cortes may best be described qualitatively by treating the large rock outcrops and the areas beneath them separately.

On the outcrops were dense patches of Eisenia arborea forming a canopy about $1 \mathrm{~m}$ high. Below this canopy lived many small and medium sized foliose brown and red algae such as Dictyota spp., Pachydictyon coriaceum, Cystoseira neglecta, and Rhodymenia spp. Invertebrates in the understory community
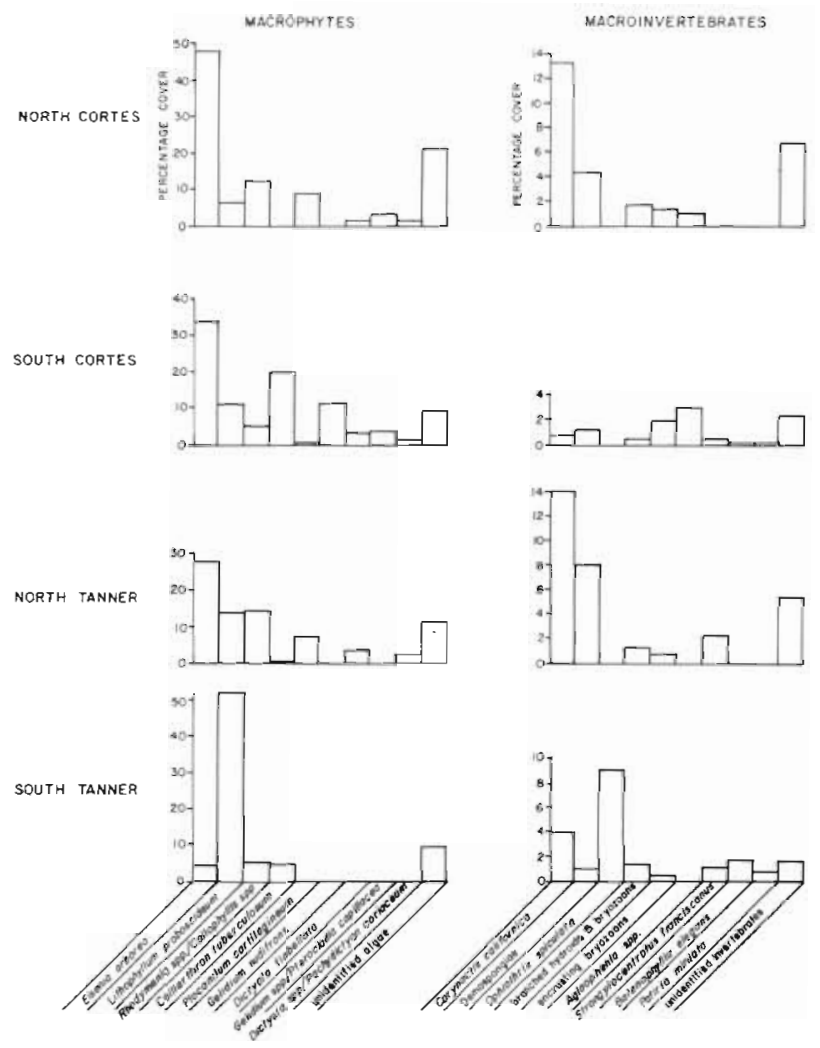

Fig. 5. Distribution of abundance in transects by percentage cover of dominant macrophytes and macroinvertebrates

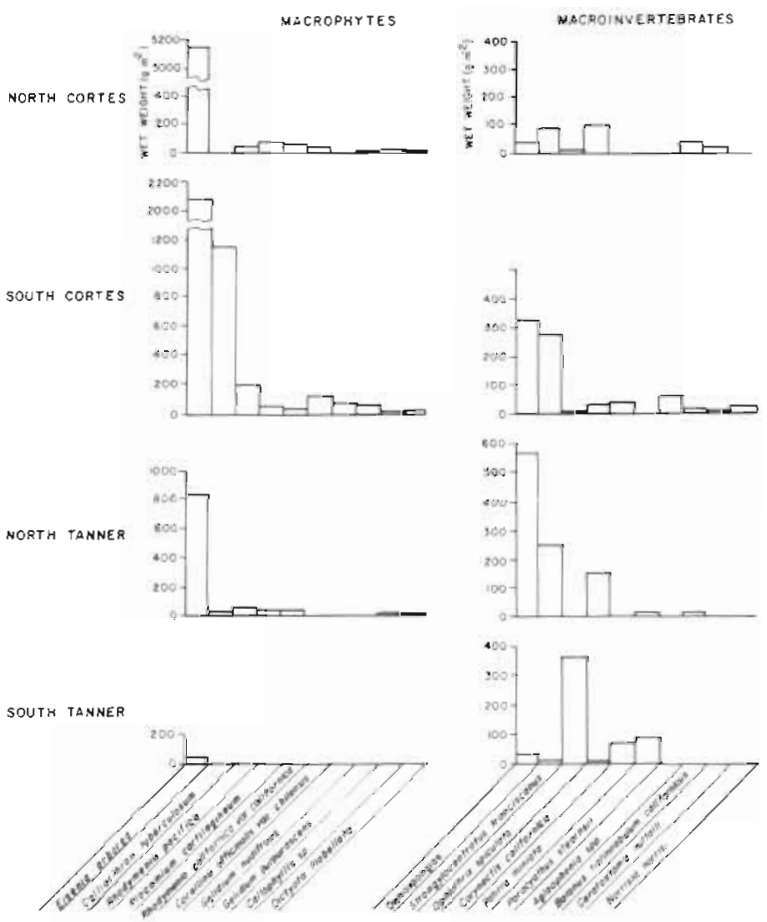

Fig. 6. Distribution of abundance in harvested quadrats by wet weight of dominant macrophytes and macroinvertebrates 
included Aglaophenia spp., Corynactis californica, Balanus tintinnabulum californicus, and many sponges and tunicates.

Eisenia arborea was less dense in the areas below the rock outcrops. The brown alga Laminaria farlowi formed huge sheets lying along the bottom in some locations, while elsewhere articulated coralline algae such as Corallina officinalis var. chilensis and Calliarthron tuberculosum occurred together. Exposed rocks were covered with the encrusting red coralline alga Lithophyllum proboscideum. Invertebrates included the forms mentioned above as well as larger species such as the crabs Pugettia dalli, Cancer jordani, and Loxorhynchus crispatus; the sea stars Pisaster giganteus, Henricia leviuscula, and Patiria miniata; the urchins Strongylocentrotus purpuratus and $S$. franciscanus; and numerous gastropods, especially Norrisia norrisi. Cnidarians in this habitat included the solitary corals Balanophyllia elegans and Paracyathus stearnsii and the large red anemone Tealia sp. Spiny lobsters (Panulirus interruptus) and abalones (Haliotis spp.) inhabited crevices in rock outcrops. In all, 45 macrophyte taxa and 108 macroinvertebrate taxa were recognized (Fig. 3A, Table 1). Rhodophyta was the largest division among the algae while Mollusca was the largest invertebrate phylum in terms of numbers of species (Fig. 4).

Eisenia arborea was the dominant alga by percentage cover in the transects (34\%), while Calliarthron tuberculosum, Lithophyllum proboscideum, and Gelidium nudifrons were also prominent (Fig. 5). Total macrophyte cover (overstory plus understory) was $127 \%$, while total macroinvertebrate cover was $11 \%$. Aglaophenia spp. and encrusting bryozoans were the most abundant macroinvertebrates by percentage cover, but together they occupied little more than $5 \%$ of the substrate. Diversity $\left(\mathrm{H}^{\prime}\right)$ for macroinvertebrates, macrophytes, and both combined averaged 1.31, 2.02, and 2.16 respectively (Fig. 3B). Corresponding evenness $\left(\mathrm{J}^{\prime}\right)$ values were $0.47,0.67$, and 0.60 (Fig. $3 \mathrm{C}$ )

In the harvested quadrats, Eisenia arborea and Calliarthron tuberculosum dominated all other macroalgae by wet weight (Fig. 6). The total average biomass at this station was $4871 \mathrm{~g} \mathrm{~m}^{-2}$ (Fig. 3D), of which $43 \%$ was due to E. arborea, $25 \%$ to $C$. tuberculosum and $12 \%$ to various sponges plus Strongylocentrotus franciscanus.

\section{North Tanner}

The North Tanner study site was located at a depth of almost $26 \mathrm{~m}$ near the edge of a plateau. Adjacent to the plateau the bottom dropped abruptly to depths of more than $40 \mathrm{~m}$. The transects ran roughly parallel to the edge of this underwater cliff and crossed a few low walls and ridges. Several major habitat types were found in the study area. Along the tops of the ridges and on the cliff edge Eisenia arborea formed a canopy in which large heads of the hydrocoral Allopora californica were growing. These areas were swept by particularly strong currents and had little unconsolidated sediment. Beneath the algal canopy were smaller brown and red algae, as well as Corynactis californica and various sponges. Below the ridge tops, in flat areas only a few meters deeper, $A$. californica did not occur and E. arborea was sparse. There was, instead, a low-profile community of algae and invertebrates with the most space covered by a smooth layer of Lithophyllum proboscideum. Breaks in this coralline crust were usually occupied by patches of $C$. californica and of the green alga Codium hubbsii. Other common macroalgae included Opuntiella californica and numerous articulated coralline reds. Hydroids, sponges, bryozoans, and solitary corals were also distributed in patches on the crust, while echinoderms such as Henricia leviuscula and Strongylocentrotus franciscanus roamed its surface.

A total of 38 macrophyte taxa and 111 macroinvertebrate taxa were identified at North Tanner (Fig. 3A, Tabel 1). Rhodophyta contained the most macrophyte taxa, while Mollusca had the most macroinvertebrate taxa (Fig.4). Eisenia arborea was the dominant alga in the transects (28\% cover) (Fig. 5). Lithophyllum proboscideum and Rhodymenia spp./Callophyllis spp. (indistinguishable in photographs) each accounted for about half as much cover as E. arborea. Total macrophyte cover was $93 \%$ (overstory plus understory). Total macroinvertebrate cover was $33 \%$, of which Corynactis californica (14\% cover) and sponges ( $8 \%$ cover) were most prominent. Diversity $\left(\mathrm{H}^{\prime}\right)$ for macroinvertebrates, macrophytes, and both combined averaged $0.72,1.72$, and 2.02, respectively (Fig. 3B). Corresponding evenness $\left(\mathrm{J}^{\prime}\right)$ values were $0.25,0.61$, and 0.57 (Fig. 3C).

The average harvested quadrat contained $2271 \mathrm{~g}$ $\mathrm{m}^{-2}$ wet weight (Fig. 3D), divided nearly equally between macrophyte and macroinvertebrate biomass. Eisenia arborea was the dominant macrophyte $(845 \mathrm{~g}$ $\left.\mathrm{m}^{-2}\right)$, while sponges, Corynactis californica, and Stronglycentrotus franciscanus together accounted for $979 \mathrm{~g} \mathrm{~m}^{-2}$ (Fig. 6).

\section{South Tanner}

The South Tanner site was the deepest of the four stations, located on top of a short ridge at a depth of more than $29 \mathrm{~m}$. Compared to the other sites, South Tanner looked barren due to the low physical relief 
and the paucity of large, erect algae. The whole site appeared pinkish-purple in color due to extensive cover by Lithophyllum proboscideum. Closer examination revealed a striking invertebrate community. Thousands of brittle stars (Ophiothrix spiculata) carpeted the bottom, while the orange cup coral Balanophyllia elegans was in great abundance on the smooth surfaces. The two transects at this site ran over a physically fairly homogeneous area. Except for a very gentle rise near the ends of the transects, the rocks were quite flat. The ridge lay parallel to other ridges at similar depths but was separated from them by a bed of coarse unconsolidated sediment at a depth of about $40 \mathrm{~m}$.

The species assemblage at South Tanner was similar to that described above for the coralline crust at North Tanner, wi h the addition of high densities of the echinoderms Ophiothrix spiculata, Patiria miniata, Strongylocentrotus purpuratus, and $S$. franciscanus. Four species of large gastropods were also common: the chestnut cowrie Cypraea spadicea, the queen turban Tegula regina, the ringed top shell Calliostioma annulatum, and the brick-red top shell Astraea gibberosa. Twenty-six macrophyte taxa and 72 macroinvertebrate taxa were identified (Fig. 3A, Table 1). Rhodophyta and Mollusca, once again, were the phyla with the greatest number of taxa (Fig. 4). The brown macroalgae were represented by only two species (Eisenia arborea and Laminaria farlowil) at this deep site.

Lithophyllum proboscideum dominated algal cover $(51 \%)$, while Ophiothrix spiculata $(9 \%)$ and Corynactis californica $(4 \%)$ were the most visible macroinvertebrates in the transects (Fig. 5). Total coverage was $85 \%$ for the macroalgae and $22 \%$ for the macroinvertebrates. Diversity $\left(\mathrm{H}^{\prime}\right)$ for macroinvertebrates, macrophytes, and both combined averaged 1.47, 0.88, and 1.52 , respectively (Fig. 3B). Corresponding evenness values were $0.49,0.34$, and 0.43 (Fig. 3C).

Ninety percent of the biomass in the harvest quadrats at South Tanner was due to macroinvertebrates. The total wet weight averaged $675 \mathrm{~g} \mathrm{~m}^{-2}$ (Fig. 3D), of which Ophiothrix spiculata alone accounted for $365 \mathrm{~g}$ $\mathrm{m}^{-2}$ (Fig. 6).

\section{COMPARISON AMONG STATIONS AND DISCUSSION}

Two contrasting subtidal communities on Cortes and Tanner Banks could be distinguished in this study. At the North Cortes study site and in general in shallow areas less than $25 \mathrm{~m}$ deep, the Eisenia arborea forest community was most common, with its associated understory algae (Dictyota flabellata, Pachydictyon coriaceum, Plocamium cartilagineum, and Rhodymenia spp.) and invertebrates (Corynactis californica, Aglaophenia spp. and Abietinaria spp.). At the South Tanner study site and at other areas deeper than $25 \mathrm{~m}$, a community dominated by a smooth, hard crust of Lithophyllum proboscideum and, in patches, Corynactis californica, Paracyathus stearnsii, Balanophyllia elegans, and Ophiothrix spiculata was characteristic. The clear dichotomy between Eisenia arborea forest and encrusting coralline communities was best observed on tall pinnacles in the area surrounding the South Tanner site. The tops of these pinnacles were covered with E. arborea and Allopora californica. A short distance down were bands of Corynactis californica interspersed with Lithophyllum proboscideum dotted by solitary corals. Below $25 \mathrm{~m}$, even on flat ledges, the coralline crust community remained dominant; if $E$. arborea was present, it was sparse, and individual plants appeared greatly reduced in size compared to the $1-\mathrm{m}$ tall plants seen at shallower locations.

Other surveys of Cortes and Tanner Banks have described similar communities in less detail (Smith, 1976; Ecomar, 1978). A recent submersible survey reported these two communities may be seen at some locations at greater depths as well as two other communities on rocky substrates: a community dominated by the brown algae Agarum fimbriatum and Laminaria farlowii from $40-60 \mathrm{~m}$, and a deep community $(89-149 \mathrm{~m})$ characterized by ophiuroids and by the crinoid Florometra serratissima (Interstate Electronics Corporation, 1979).

Community biomass on Cortes and Tanner Banks decreased sharply with depth at our four stations (Fig. 3D). The decrease in biomass was due to changes in macrophyte biomass, primarily. While macrophyte biomass exceeded macroinvertebrate biomass at the shallower stations on Cortes Bank, the two were nearly equal at the transitional North Tanner site, and macroinvertebrate biomass exceeded algal biomass at the deepest station, South Tanner.

The total number of macrophyte taxa (all sampling methods) declined with depth (Fig. 3A). However, the number of macroinvertebrates and macrophytes combined showed a pattern in which the two sites intermediate in depth (South Cortes and North Tanner) had higher numbers of taxa than the shallowest or deepest sites. This same pattern emerged when diversity was plotted against depth (Fig. 3B). The shallowest and deepest sites had the lowest $H^{\prime}$ values (based on percentage cover along the transects) while the intermediate-depth stations were the most diverse. The values of $\mathrm{H}^{\prime}$ largely reflected macrophyte diversity, since algal cover was generally much greater than invertebrate cover. 
Table 1. Macrophyte and macroinvertebrate taxa identified at Cortes and Tanner Banks. Refer to text for explanation of sampling methods and omission of some invertebrate groups. NC: North Cortes, SC: South Cortes, NT: North Tanner, ST: South Tanner

MACROPHYTES

\section{CHLOROPHYTA}

\section{Codium cuneatum}

Codium hubbsii

Codium setchellii

Derbesia manina

Halicystis ovalis

Unidentified chlorophyte spp

\section{PHAEOPHYTA}

Colpomenia sp.

Cystoseira osmundacea/neglecta

Dictyopteris undulata

Dictyota binghamiae

Dictyota flabellata

Eisenia arbore

Laminaria farlowii

Pachydictyon coriaceum

Zonaria farlowii

\section{RHODOPHYTA}

Asparagopsis taxiformis

Bossiella orbigniana ssp. dichotoma

Bossiella orbigniana ssp. orbigniana

Botryocladia pseudodichotoma

Calliarthron tuberculosum

Callophyllis firma

Callophyllis sp.

Carpopeltis bushiae

Carpopeltis divaricata

Ceramium spp.

Coeloseira compressa

Corallina officinalis var. chilensis

Corallina vancouveriensis

Cryptopleura corallinara

Cryptopleura crispa

Cryptopleura spp.

Gelidium nudifrons

Gelidium purpurascens

Gelidium robustum

Gelidium spp.

Gigartina sp

Griffithsia pacifica

Gymnogongrus leptophyllus

Halymenia coccinea

Herposiphonia plumula

Heterosiphonia erecta

Laurencia spectabilis

Laurencia spp.

Lithothamnium pacifica

Lithophyllum proboscideum

Lithophyllum spp.

Microcladia coulteri

Nienburgia andersoniana

Opuntiella californica

Ozophora spp.

Plocamium cartilagineum

Polysiphonia acuminata

Polysiphonia hendryi var. hendryi

Polysiphonia spp

Pterosiphonia baileyi

Pterosiphonia dendroidea

Rhodoglossum affine

Rhodymenia californica var, attenuata
Rhodymenia californica var californica

Rhodymenia pacifica

Rhodymenia sp.

Unidentified crustose rhodophyte sp.

$\begin{array}{llll}x & x & x \\ x & x & x & x\end{array}$

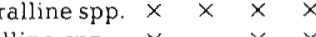

Unidentified foliose rhodophyte spp. $\times \times \times \times$

$\times \begin{aligned} & x \\ & \times\end{aligned} \times x$

\section{MACROINVERTEBRATES}

PORIFERA

Demospongiae

Haliclona sp

Hynectyon byle

Microciona parthena

Mycale psila

Myxilla incrustans

Penares cortius

Plocamia karykina

Plocamilla illgi

Stelleta estrella

Suberites ficus

Tethya aurantia

Calcarea

Leucandra heathi

$\begin{array}{llllllll}x & x & x & x\end{array}$

$\times x \times x$

$\times \quad \times$

COELENTERATA

Hydrozoa

Abietinaria sp., near expansa

Abietinaria spp.

Aglaophenia diegoensis

Aglaophenia sp.

Allopora californica

Sertularella solitaria

Sertularella turgida

Sertularella spp.

Unidentified branched hydroid spp.

Anthozoa

Anthopleura xanthogrammica

Balanophyllia elegans

Charisea sp.

Corynactis californica

Epiactis prolifera

Paracyanthus stearnsii

realia coriacea

Tealia sp.

$x+x$

$\times \times x$

$x$

$x$

$x \times x$

$\times \quad \times \quad x$

$x \quad x$

$x \times x \times$

$x$

$x \times x$

$x+x$

ECHINODERMATA

Asteroidea

Henricia leviuscula

Mediaster aequalis

Orthasterias koehler

Patiria miniata

Pisaster giganteus

$x$

$\times$

$\times \quad x$

$\times$

$x$

$\times$

Echinoidea

Strongylocentrotus franciscanus

Strongylocentrotus purpuratus

$x \times x$

$x \times x$

Amphipodia occidentalis 
Table 1. (Continued)

NC SC NT ST

NC. SC NT ST

Amphipholis pugetana

Amphipholis squamata

Amphipholis spp.

Ophiactis simplex

Ophiocantha spp.

Ophioeryptus spp

Ophioncus granulosus

Ophionereis eurybrachyplax

Ophioplocus esmarki

Ophiopteris papillosa

Ophiothrix spiculata

Holothuroidea

Parastichopus parvimensis

Psolus sp.

ANNELIDA

Polychaeta

Dodecaceria concharum

Dodecaceria fewkesi

Pseudopotamilla exoyura

Spirobranchus spinosus

Unidentified colonial tubeworm spp.

ECTOPROCTA

Lichenopora sp./Disporella sp.

Phidolopora pacifica

Unidentified branched bryozoan spp.

Unidentified encrusting bryozoan spp.

CHORDATA

Urochordata

Archidistoma psammion

Clavelina huntsmani

Distaplia occidentalis

Ritterella pulchra

Styela plicata

Unidentified tunicate spp.

MOLLUSCA

Polyplacophora

Callistochiton crassicostatus

Callistochiton decoratus

Callistochiton sp.

Chaetopleura gemma

Chaetopleura sp.

Cryptochiton stelleri

Cyanoplex dentiens

Cyanoplex lowei

Dendrochiton thamnoporus

Ischnochiton sp.

Leptochiton spp.

Placiphorella velata

Schizoplax brandtis

Schizoplax sp.

Pelecypoda

Chama pellucidea

Chlamys hastata

Gregariella chenuj

Hiatella arctica

Hinnites giganteus

Kellia laperousii

Lima hemphilli

Lithophaga plumula

Modiolus capax

Modiolus carpenteri

Modiolus neglectus

Modiolus spp.

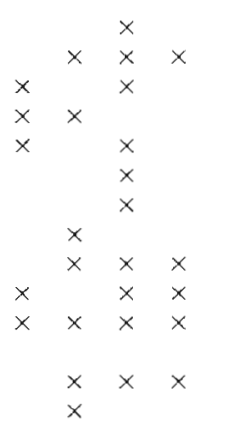

Philobrya setosa

Pododesmus cepio

Pododesmus pernoides

Pseudochama exogyra

Gastropoda $=$ Prosobranchia

Acmaea (Acmaea) mitra

Acmaea (Acmaea) rosacea

Acmaea (Colisella) triangularis

Amphissa versicolor

Astraea gibberosa

Astraea undosa

Balcis spp.

Balcis thersites

Calliostoma annulatum

Calliostoma gemmulatum

Calliostoma gloriosum

Calliostoma supragranosum

$\times \quad \times \quad$ Ceratostoma nuttalli

Cerithiopsis carpenteri

Cerithropsis cosmia

Cerithiopsis spp.

Conus californicus

Crepipatella lingulata

Cypraea spadicea

$\begin{array}{llll}x & \times & \times & \times \\ & & x & \\ x & \times & \times & \times\end{array}$

Cystiscus politulus

Dendropoma lituella

Diodora arnoldi

Epitonium tinctum

Erato columbella

Fusinus luteopictus

Granulina margaritula

Haliotis corrugata

Haliotis sp

Hipponix tumens

Homalopoma paucicostatum

Homalopoma radiatum

Lacuna porrecta

Lamellaria diegoensis

Latiaxis oldroydi

Lirularia acutiscostata

Maxwellia gemma

Maxwellia santarosana

$\times \times \times \times$

$x$

$\times \quad$ Megathura cremulata

$\times \times \quad$ Metaxia convexa

Mitra idae

Mitrella aurantiaca

Mitrella carinata

$\times \quad x$

$\times \times \times \times \quad$ Mitromorpha aspera

Mitromorpha carpenter

Murexiella santarosana

Norrisia norrisi

Nucella (Thais) canaliculata

Ocenebra atropurpurea

Ocenebra gracillima

Parviturbo acuticostatus

Seila montereyensis

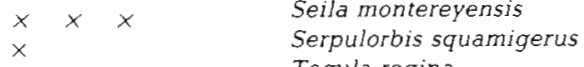

Tegula regina

Tricolla pulloides

Triphora catalinensis

Triphora pedroana

Trivia califomiana

Turbonilla kelseyi

Volvarina taeniolata

Gastropoda = Opisthobranchia

Aldisia sanguined

Ansodoris nobilis
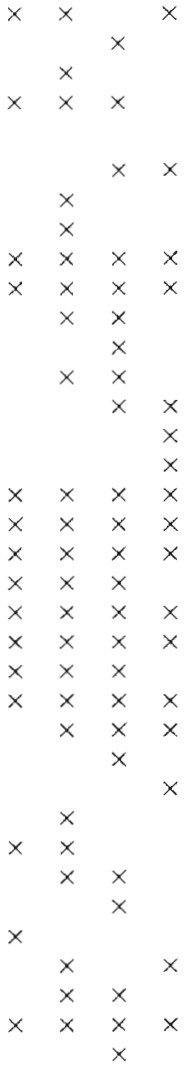

$\times$

$\times$

$\times$

$x$

$$
\begin{aligned}
& x \\
& x
\end{aligned}
$$$$
x
$$$$
\begin{aligned}
& x \\
& x
\end{aligned}
$$$$
x
$$$$
x
$$$$
x
$$$$
x \times x \times
$$$$
x
$$$$
\times
$$$$
x \times x
$$$$
\times
$$$$
x \times x
$$$$
x \quad x
$$$$
x
$$

$\times$
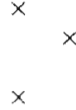

$\times$

$\times \quad x$

$x \times x$ 
Table 1. (Continued)

\begin{tabular}{|c|c|c|c|c|c|c|c|c|c|}
\hline \multicolumn{6}{|c|}{ NC SC NT ST } & \multicolumn{4}{|c|}{ NC SC NT ST } \\
\hline Aplysia sp. & & & $\times$ & & Lophopanopeus leucomanus heathii & $x$ & & & \\
\hline Cadlina luteomarginata & & & & $\times$ & Loxorhynchus crispatus & $x$ & $x$ & x & $x$ \\
\hline Cadlina modesta & & $x$ & & & Paguristes ulreyi & & & & $x$ \\
\hline Cadlina sparsa & & & $x$ & & Pagurus hirsutiusculus & $x$ & & & \\
\hline Cadlina spp. & & & $x$ & & Pagurus setosus & & & $x$ & \\
\hline Discodoris heathi & $\times$ & & & & Pagurus spp. & & $x$ & $x$ & $x$ \\
\hline Doriopsilla albopunctata & $\times$ & $x$ & $x$ & & Panulirus interruptus & $x$ & $x$ & & \\
\hline Dons sp. (sensu lato\} & & $x$ & & & Paraxanthias taylori & $x$ & $x$ & $x$ & $x$ \\
\hline Flabellinopsis iodinea & $x$ & $x$ & $x$ & & Pugettia dalli & $x$ & $\times$ & & \\
\hline Hermissenda crassicornis & & & $x$ & $x$ & Pugettia richii & & $x$ & & \\
\hline Phidiana pugnax & $x$ & $x$ & & & Pugettia producta & & & $\times$ & \\
\hline Triopha carpenteri & & & $x$ & & Pylopagurus califoriensis & $x$ & & & \\
\hline \multirow[t]{2}{*}{ Unidentified nudibranch spp. } & $\times$ & $x$ & $x$ & $x$ & Pylopagurus diegensis & $x$ & $\times$ & $x$ & \\
\hline & & & & & Pylopagurus spp. & & & $x$ & \\
\hline ARTHROPODA & & & & & Scyra acutitrons & & & & \\
\hline \multicolumn{10}{|l|}{ Crustacea $=$ Cirripedia } \\
\hline Balanus tintinnabulum californicus & $x$ & $x$ & $\times$ & $\times$ & Pycnogonida & & & & \\
\hline Crustacea $=$ Malcostraca & & & & & Ammothea hilgendorfi & $x$ & $x$ & & \\
\hline Cancer jordani & $x$ & $x$ & $\times$ & & Tanystylom intermedium & & $x$ & & \\
\hline
\end{tabular}

The hump-shaped trend in diversity with depth appears to be due to changes in evenness $\left(\mathrm{J}^{\prime}\right)$ rather than to differing numbers of taxa (Fig. 3C). $\mathrm{H}^{\prime}$ is increased by greater numbers of taxa and by increased evenness in the distribution of abundance. As both Figures $3 \mathrm{~A}$ and $3 \mathrm{C}$ indicate, the higher diversity values at South Cortes and North Tanner were functions of more equitable distributions of abundance among the species present. However, different environmental conditions are believed to be responsible for the high diversity at each of the two sites.

The South Cortes site differed from all of the others in having large cobbles and small boulders up to about $20 \mathrm{~cm}$ in diameter mixed with shelly debris in depressions around larger rocks. Water movement at this site (21 $\mathrm{m}$ deep) was strong enough to lift our $70 \mathrm{~kg}$ lead transect markers out of holes $20 \mathrm{~cm}$ deep and move them tens of meters away. Given this heavy surge and the presence of loose sediment, the lower-lying rocks and their attached biota must periodically be subjected to severe scouring. Abraded substrate would be available to settling organisms such as algal spores and invertebrate larvae, while the lack of a solid Eisenia arborea canopy would ensure high light levels for settlers. Thus mechanical disturbance may act to retard ecological succession. Higher community diversity would result from the maintenance of ecologically subdominant forms (Paine, 1966), which would be competitively excluded from a climax community such as an E. arborea forest.

At North Tanner the relatively high evenness and diversity values are believed to have resulted from sampling a mixture of two communities. The rather abrupt change in community composition with depth at the North Tanner site suggests that in the absence of abrasive crust disturbance, competitive interactions between Lithophyllum proboscideum and Eisenia arborea may reach a critical value at a depth near $25 \mathrm{~m}$. Two lines of evidence may be cited: First, E. arborea is capable of living at a depth as great as $40 \mathrm{~m}$ in the clear water of this area, but its size decreases sharply below $30 \mathrm{~m}$ (Interstate Electronics Corporation, 1979). Second, L. proboscideum showed extremely rapid recovery rates after being scraped at South Tanner. As little as one month after we scraped off all living material in experimental quadrats, $L$. proboscideum had completely regrown over the area and no damage was visible. This observation suggests that rapid growth rates may be responsible for the dominance of $L$. proboscideum over other algae at our deep sites. North Tanner showed a mosaic of both $E$. arborea and $L$. proboscideum communities and consequently exhibited high diversity values.

The organisms reported in this study (Table 1) are also found in rocky subtidal habitats along the coast of central and southern California and on the Channel Islands. Nevertheless, the geographic, bathymetric, and hydrographic setting that makes Tanner and Cortes Banks unique oceanographic features of southern California's outer continental shelf has produced subtidal communities with different relative abundances and depth ranges from those typical of mainland and Channel Island coastal zones. For example, Eisenia arborea does not extend below $8 \mathrm{~m}$ at Anacapa Island (Neushul et al., 1967); $10 \mathrm{~m}$ at Santa Catalina Island (Abbott and Hollenberg, 1976); and $12 \mathrm{~m}$ at Corona del Mar (Lippincott, 1978), whereas it grows as deep as $40 \mathrm{~m}$ on Tanner Bank (Interstate Electronics Corporation, 1979). Species such as Allopora californica and Cypraea spadicea, which are often col- 
lected for souvenirs or jewelry along the coast are in much greater abundance on Tanner and Cortes Banks (Smith, 1976), as are more common species such as Corynactis californica (compare McLean, 1962; Pequegnat, 1964; Turner et al., 1968; Rosenthal et al., 1974). Offshore banks and islands also appear to serve as refuges for relict species (Newman and Ross, 1977) and previously undiscovered taxa, such as the monoplacophoran limpet Vema hyalina found near our study sites (McLean, 1979). Furthermore, some species common in rocky habitats in southern California are conspicuously absent on Cortes and Tanner Banks. These species include the giant kelp Macrocystis pyrifera, the palmate kelp Pterygophora californica, and the gorgonians Muricea californica (= M. appressa) and M. fruticosa. The top of Cobb Seamount, which lies $490 \mathrm{~km}$ off the coast of North America and is isolated by very deep water, also appears to have fewer species than the mainland (Birkeland, 1971).

Cortes and Tanner Banks lie farther offshore than any other shallow-water habitat off the coast of California or Oregon, but they are only semi-isolated biogeographically. Species with long-lived larvae could easily be carried there by currents. Moreover, Cortes and Tanner Banks are connected at a depth of $500 \mathrm{~m}$ to the central California mainland and the northern Channel Islands by the Santa Rosa-Cortes Ridge (Fig. 1). Prehistoric sea-level and/or tectonic changes along this relatively shallow ridge probably allowed the Banks to be populated originally by many nearshore species, even by some, such as Allopora californica (Ostarello, 1976) and Balanophyllia elegans (Gerrodette, in press), known to have extremely limited larval dispersal. The subtidal communities on Cortes and Tanner Banks as a whole may thus be characterized as a subset of mainland California fauna and flora, perhaps with closer affinities to central than to southern California.

Acknowledgements. Logistic and safety support for this project were provided by Andrew D. Osterle of Science Applications, Inc., Captain Bill Johnston of the vessel 'Bottom Scratcher', and Flip Nicklin of the Diving Locker, as well as by a large and dedicated crew of research divers. The professionalism and hard work of this crew made it possible to obtain a complete set of samples with a perfect safety record under extremely challenging diving conditions. The samples were analyzed by a large group of students and technicians in the Department of Ecology and Evolutionary Biology at the University of California, Irvine.

\section{LITERATURE CITED}

Abbott, I. A., Hollenberg, G. J. (1976). Marine algae of California, Stanford University Press, Stanford, California
Birkeland, C. E. (1971). Biological observations on Cobb Seamount. Northwest Sci. 45: 193-199

Ecomar, Inc. (1978). Tanner Bank mud and cuttings study. Technical Report to Shell Oil Company from Ecomar, Inc., Santa Barbara, California. (unpubl.)

Gerrodette, T (in press). Dispersal of the solitary coral Balanophyllia elegans by demersal planular larvae. Ecology 62 (1982)

Interstate Electronics Corporation (1979). Biological and geological reconnaisance and characterization survey of the Tanner and Cortes Banks. Technical Report to the U.S. Bureau of Land Management from Interstate Electronics Corporation, Anaheim, California. (unpubl.)

Lippincott, W. H. (1978). Southern California baseline study, intertidal, year two final report, summary and synthesis, Vol. 2. Technical Report to the U.S. Bureau of Land Management from Science Applications, Inc., La Jolla, California. (unpubl.)

Littler, M. M. (1971). Standing stock measurements of crustose coralline algae (Rhodophyta) and other saxicolous organisms. J. exp. mar. Biol. Ecol. 6: 91-99

McLean, J. H. (1962). Sublittoral ecology of kelp beds of the open coast near Carmel, California. Biol. Bull. mar. biol. Lab., Woods Hole 122: 95-114

McLean, J. H. (1979). A new monoplacophoran limpet from the continental shelf off southern California. Contrib. Sci. Nat. Hist. Mus. Los Angeles County 307: 1-19

Neushul, M., Clarke, W. D., Brown, E. W. (1967). Subtidal plant and animal communities of the southern California islands. In: Philbrick, R. N. (ed.) Proceedings of the symposium on the biology of the California Islands. Santa Barbara Botanic Garden Publ., Santa Barbara, California

Newman, W. Ross, A. (1977). A living Tesseropora from Bermuda and the Azores: first record from the Atlantic since the Oligocene. Trans. San Diego Soc. Nat. Hist. 18: $207-216$

Ostarello, G. L. (1976). Larval dispersal in the subtidal hydrocoral Allopora californica Verrill (1866). In: Mackie, G. O. (ed.) Coelenterate ecology and behavior. Plenum Press, New York, pp. 331-337

Paine, R. T. (1966). Foodweb complexity and species diversity. Am. Nat. 100: 65-75

Pequegnat, W E. (1964). The epifauna of a California siltstone reef. Ecology 45: 272-283

Pielou, E. C. (1966a). Shannon's formula as a measure of specific diversity: its use and misuse. Am. Nat. 100: 463-465

Pielou, E. C. (1966b). The measurement of diversity in different types of biological collections. J. theor. Biol. 13: 131-144

Rosenthal, R. J., Clarke, W. D., Dayton, P. K. (1974). Ecology and natural history of a stand of giant kelp. Macrocystis pyrifera, off Del Mar, California. Fish. Bull. U.S. 72: 670-684

Smith, S. H. (1976). Report of the preliminary biological assessment of Tanner Bank and Cortes Bank offshore southern California. Interoffice Technical Report, U.S. Bureau of Land Management, Los Angeles, California. (unpubl.)

Turner, C. H., Ebert, E. E., Given, R. R. (1968). The marine environment offshore from Point Loma, San Diego County. Calif. Fish Game Fish. Bull. 140: 1-85 